\title{
Evidence for phenotypic plasticity in response to photic cues and the connection with genes of risk in schizophrenia
}

\author{
Christine L. Miller * \\ MillerBio, Baltimore, MD, USA
}

\section{Edited by:}

Tim Karl, Neuroscience Research Australia, Australia

Reviewed by:

Randy J. Nelson, The Ohio State University, USA

Miou Zhou, University of California Los Angeles, USA

Tim Karl, Neuroscience Research Australia, Australia

\section{*Correspondence:}

Christine L. Miller, MillerBio, 6508 Beverly Rd., Baltimore, MD 21239, USA

e-mail:cmiller@millerbio.com
Numerous environmental factors have been identified as influential in the development of schizophrenia. Some are byproducts of modern life, yet others were present in our evolutionary past and persist to a lesser degree in the current era. The present study brings together published epidemiological data for schizophrenia and data on variables related to photic input for places of residence across geographical regions, using rainfall as an inverse, proxy measure for light levels. Data were gathered from the literature for two countries, the former Yugoslavia and Ireland, during a time in the early 20th century when mobility was relatively limited. The data for Yugoslavia showed a strong correlation between hospital census rates for schizophrenia (by place of birth) and annual rain $(r=0.96, p=0.008)$. In Ireland, the hospital census rates and first admissions for schizophrenia (by place of permanent residence) showed a trend for correlation with annual rain, reaching significance for 1 st admissions when the rainfall data was weighted by the underlying population distribution $(r=0.71, p=0.047)$. In addition, across the years 1921-1945, birth-year variations in a spring quarter season-of-birth effect for schizophrenia in Ireland showed a trend for correlation with January-March rainfall $(r=0.80, p \leq 0.10)$. The data are discussed in terms of the effect of photoperiod on the gestation and behavior of offspring in animals, and the premise is put forth that vestigial phenotypic plasticity for such photic cues still exists in humans. Moreover, genetic polymorphisms of risk identified for psychotic disorders include genes modulated by photoperiod and sunlight intensity. Such a relationship between phenotypic plasticity in response to a particular environmental regime and subsequent natural selection for fixed changes in the environmentally responsive genes, has been well studied in animals and should not be discounted when considering human disease.

Keywords: schizophrenia, pyschoses, epidemiology, photoperiod, natural light, prenatal, melanotropin, vitamin D

\section{INTRODUCTION}

The epidemiology of psychiatric disease represents an invaluable resource for new insights into gene-environment interactions as a cause of mental illness. That epidemiological variation in incidence must occur across space and time is consistent with known principles for all human disease, be the cause predominantly environmental or genetic. Although no field of endeavor is so fraught with potentially confounding variables, the perceived difficulties in interpretation should not lead to a blanket rejection of such work. As evidence builds for a consistent trend between studies, and as data mounts from research avenues in genetics and pharmacology that support the epidemiologic results, the resulting knowledge can be used to more productively design future research. Such is the case with three epidemiologic outcomes for schizophrenia that are likely related: the effect of latitude on rates of disease in the indigenous population, the effect of immigration from southern to northern latitudes and the late winter-to-spring quarter season of birth effect, a modest but consistent finding that has survived mathematical challenges (Lewis and Griffin, 1981; Dalén, 1990; Pulver et al., 1990; Watson, 1990), and questions as to its relevance in the Southern hemisphere
(McGrath and Welham, 1999), where the effect is much less robust.

One key environmental link between the epidemiological studies and related genetic/pharmacologic results is photic input (McGrath et al., 2002), a factor also of relevance to the melanotropin genes shown to be associated with psychotic disorders including schizophrenia (Severinsen et al., 2006; Miller et al., 2009; Demontis et al., 2012) and of relevance to pharmacological results that pertain to the function of those genes (Miller, 2013). If photic input is the key variable, the less pronounced Southern hemisphere results actually bolster the season-of-birth theory because a much lower percent of populated land mass occurs at the higher latitudes in the southern hemisphere than in the Northern. Importantly, Brisbane, the most populous city in the McGrath et al. study of Australia (2002), rests at latitude $27.5^{\circ} \mathrm{S}$. Dublin, in contrast, is at latitude $53.4^{\circ} \mathrm{N}$. A meta-analysis of published season of birth studies demonstrated that the effect does go up with increasing latitude (Davies et al., 2003). Furthermore, variation in overall schizophrenia incidence would be expected to vary with latitude, and a meta-analysis by McGrath and colleagues (Saha et al., 2006) demonstrated unequivocally that a 
gradient exists. This conclusion conflicts with an earlier report sponsored by the World Health Organization (WHO) discounted any correlation with latitude (Jablensky et al., 1992), but their results were somewhat compromised by selective inclusion of one study site in the final report but not another (Chandigarh, an area with a large Sikh population was included, but not Agra, an area with a large Muslim population). Data from their preliminary report (Sartorius et al., 1986) showed a nearly 10-fold difference between the two sites, but the final report (Jablensky et al., 1992) deemed that only suspected methodological differences could explain such geographical variation in incidence on such a small scale despite the fact that differences in racial composition alone could be the basis for those differences. For the study site in Ireland, a country previously reported to have a very high incidence of schizophrenia (Walsh, 1968; Kelleher et al., 1974), the WHO study team selected Dublin as a center for data collection, a region in Ireland not reported to have the high 1st admission rates for schizophrenia more characteristic of the west of Ireland (Kelleher et al., 1974).

When examining the effect of an environmental variable, it is always helpful to first look at the extremes. Nowhere has lack of photic input exerted more effects on humans over time than in the high latitude country of Ireland, where comparatively low dietary vitamin D and the lack of sunlight-induced vitamin D selected for the fairest skin type in the world, as reported in dermatological surveys (Gibson et al., 1997). Yet, although most Swedish residents live at higher latitudes than the Irish, their proportion of skin type 1 and 2 is not as high (Karlsson et al., 2000; Rodvall et al., 2007). Even in the far reaches of populations in the Arctic Circle, the impact of low light on skin type prevalence (Karlsson et al., 2000) was not so extreme, most likely because a diet rich in vitamin $\mathrm{D}$ from seafood helped to mitigate the lack of sun. The relationship between a diet rich in fatty fish and serum levels of vitamin D is clear (Burgaz et al., 2007).

McGrath and Welham (1999) have proposed that vitamin D availability may modulate the eventual development of schizophrenia, and Kinney et al. (2009) have extended that theory to propose the risk for schizophrenia around the world is related to levels of vitamin $\mathrm{D}$ from fish in their current diet. A complementary hypothesis is that a diet rich in fatty fish actually changed the evolutionary trajectory for some populations. From the time of the Vikings on, the Nordic cultures developed such a robust fishing enterprise that they exported their products to many other European destinations (Sicking and Abreu-Ferreira, 2008). The Irish, in contrast, failed to develop an historically strong sea-faring and fishing industry (Donnchadha et al., 2002), in part because the coastline toward which they were pushed during British occupation (beyond "The Pale"; McManus, 1931) was dangerously rocky and difficult to trawl (Woodham-Smith, 1962). The dire impact of this situation was most apparent during the potato famine, when a marine diet might have saved millions of lives (Donnchadha et al., 2002; Woodham-Smith, 1962). But over the generations, lacking readily available nutrients from the sea meant the resulting deficiency of vitamin D from either diet or the sun selected for an extremely fair skin type, which helped their descendents avoid rickets.
Clearly, the relative lack of sunlight had an evolutionary impact on genes affecting vitamin D generation from sunlight, but what evidence is there that it might also have selected for a change in the prevalence of a disease such as schizophrenia? Might there be vestigial phenotypic plasticity that provides a window into the forces that shaped our evolutionary past? In the animal kingdom, photic cues are crucial to survival, and animals that are adapted to life in regions of low light have evolved to have different light-responsive genotypes than those that evolved near the equator. Yet phenotypic plasticity can also be found, as evidenced by the well-studied effect of photoperiod on gestation, an effect which can not only determine coat color at birth but also neo-natal behavior (Hoffman, 1978; Reppert, 1985; Stetson et al., 1986; Weaver et al., 1987; Lee and Zucker, 1988; Nagy et al., 1993; Bellavía et al., 2006; Butler et al., 2007). Perhaps, then, the seasonof-birth effect in schizophrenia could well be evidence of vestigial phenotypic plasticity in response to seasonally varying levels of light.

The approach taken in the present study was to analyze the correlation between rates of schizophrenia and a proxy measure for photic input, rainfall. Two countries were selected for inclusion, one at a more extreme latitude, Ireland, and one at a more moderate latitude, the former Yugoslavia. No attempt was made to compare the two, as a meta-analysis of numerous country-tocountry differences has been well performed by others (Saha et al., 2006). Rather, the question being asked was whether small scale geographical differences in prevalence and incidence exist within each country and whether those differences might relate to variations in rainfall. These two countries offered the advantage of weather extremes they encompass, as well as the availability of detailed schizophrenia epidemiology during the early to mid-20th century, at a time when mobility was limited compared to today's world and when the chances were good that someone born in an area would be quite likely to grow up in the same town. The former Yugoslavia represented an opportunity to examine annual rainfall extremes within one country, as its western coastal range home to a region that receives more rainfall than any other in continental Europe, a district in the current Montenegro (Papp and Erzberger, 2007) and the nearby town of Crkvice, Croatia (Krause and Flood, 1997; Marinkovic et al., 2012), while the southern and eastern-most regions of the former country were quite dry. Ireland, on the other hand, offered the unique opportunity to investigate how photic input might relate to the season of birth data reported for birth years with the highest second quarter season-of-birth effect ever documented (O'Hare et al., 1980). As prior research has shown that rainfall 3 months before birth is significantly associated with the risk of becoming schizophrenic (Messias et al., 2001, 2006), this study focused on rainfall during the months encompassing what would have been the third trimester of gestation for births in the second quarter of the year.

\section{MATERIALS AND METHODS THE FORMER YUGOSLAVIA}

The hospitalization rates for schizophrenia by place of birth in Yugoslavia were derived from Crocetti et al. (1964). Those authors published a detailed map of the data put together by Kuljzenko (1933). During the course of one year (1931), hospitalization 
records had been obtained by Kuljzenko and co-workers for the whole of Yugoslavia and for each patient, the place of birth was noted. The scale of their plotted data was on the order of 100 sq. $\mathrm{km}$. For the purposes of this study, the epidemiological map (Crocetti et al., 1964) was digitized by a draftsman using the program AutoCad (Figure 1, top panel) to enable digital overlay of epidemiological and meteorological data. The present study relied completely on the interpretation by Crocetti et al. (1964) of Kuljzenko's publication.

The mean annual precipitation data (equivalent to rainfall) for Yugoslavia was provided by the Yugoslavian Hydrometeorological Institute (Figure 1, bottom panel). The data was for a 15 year period (1925-1940) encompassing the year of the hospital census, but not necessarily the year of birth of the patient. However, the decade-to-decade variation in rainfall is quite low ( $<7 \%$; personal communication from the former Yugoslavian Federal Hydrometeorological Institute), and more importantly,

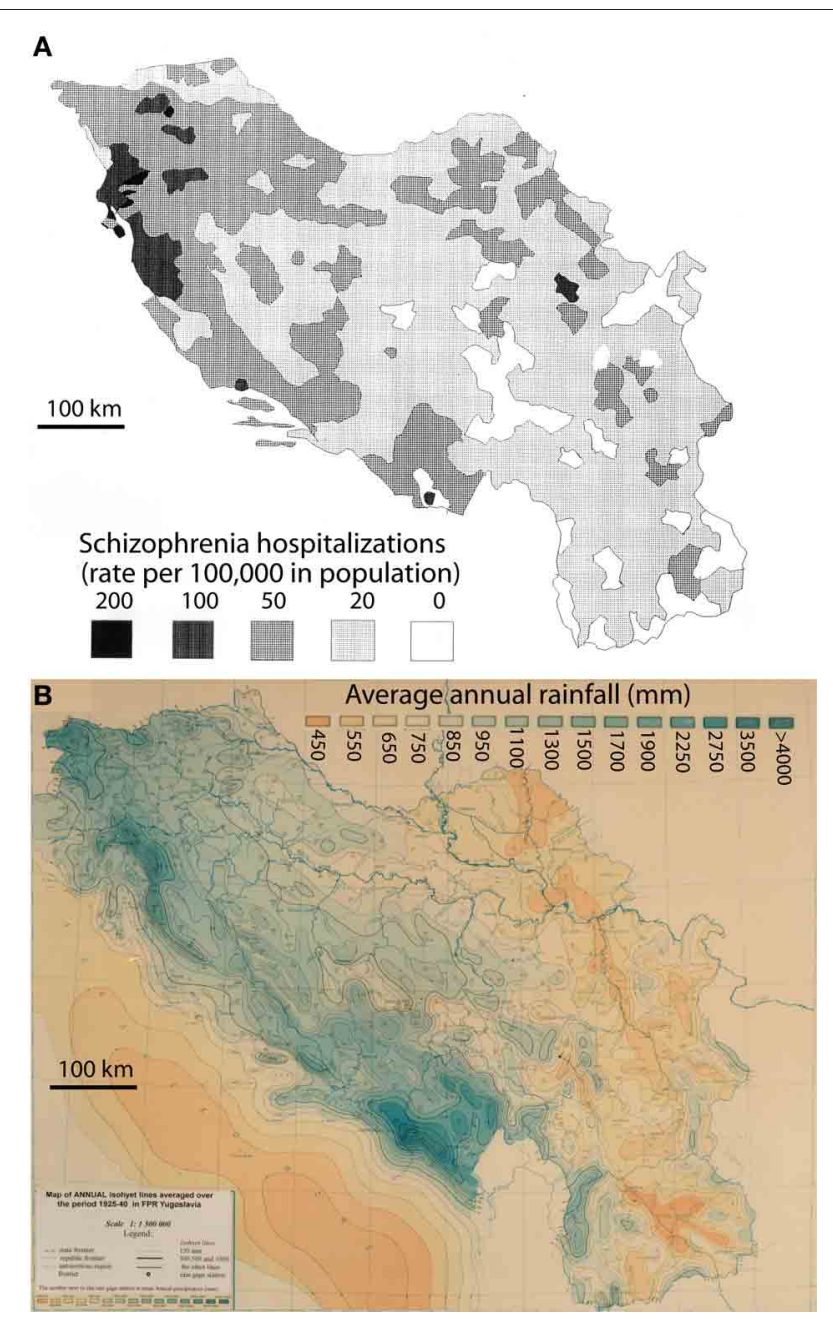

FIGURE 1 | Rates of schizophrenia hospitalization in the year 1931 (A) vs. the average annual rainfall, 1925-1940 (B) for the former Yugoslavia. The hospitalization rates are plotted by place of the patient's birth (derived from Crocetti et al., 1964). the variation in rainfall totals is unlikely to have changed the pattern of rainfall in any significant way. Data was digitized for the author by the Yugoslavian Hydrometeorological Institute and the mean annual rainfall values were calculated for 0.5 degree cells, constituting roughly $2000 \mathrm{sq}$. km. The boundaries of each cell were then superimposed on the schizophrenia hospitalization map. For each level of hospitalization rate, the corresponding cells for rainfall were tallied by the author and mean values were calculated. Where the boundary of a mapped schizophrenia hospitalization rate excluded a portion of a rainfall cell, the rainfall data was weighted by the landmass for the proportion of the cell that was included. To exclude the potentially confounding effect of different ethnic populations, regions with non-Slavic ethnic groups that represented from 5 to $\leq 100 \%$ (Figure 2) were excluded from the final analysis.

\section{IRELAND}

The Irish Health Research Board publishes yearly compilations of mental health data, including first admission rates for schizophrenia by health board catchment area, and for 1991, a country-wide census was compiled for hospitalization at midnight on March 31, 1991. The period 1982-1991 (including the census year) was used by the author to calculate the mean first admission rates for each catchment area. The catchment area sizes were approximately $4600 \mathrm{sq} \mathrm{km}$ and up.

Maps of the catchment areas for Ireland were digitized with the program AutoCad, encoded with the hospitalization rates and the 1st admission rates for schizophrenia (Figure 3, left panel). The catchment areas were then superimposed on a map of the mean annual rainfall for Ireland (Figure 3, right panel). The mean annual rain map was digitized by AutoCad from a map provided by J. J. Logue of the Irish Meteorological Service (Logue, 1984), representing rainfall data collected 1941-1970. Those years most probably included the year of birth of a good portion of the patient population creating the hospitalization and first admission rates used in this study. Since the isohyets of mean rainfall obviously did not match the boundaries of the maps for schizophrenia rates, the area covered by a given isohyet interval was digitally calculated. The percent of each catchment covered by a given isohyet interval was determined, and the mean rainfall for the region identified by summing the contribution of each area for a given isohyet interval, weighted by its percent contribution to the catchment area. The correction for population distribution (1986 census) was carried out by weighting the rainfall data by the population (as a percent of the total population in the particular catchment area) in the towns with 5,000 or more residents and assuming that the remaining land area exhibited a uniform population distribution.

Season of birth data for schizophrenia for Ireland as a whole (not available per catchment area for different years) was obtained from O'Hare et al. (1980) for births in the years 1921-1955. The data was available in 5 year increments: 1921-1925, 19261930, etc. January through March (Jan-Mar) rain for those years was available only for the years 1921-1945 (with the exception of the war year 1941), obtained in map form as a percent excess of average, from the annual publication "British 


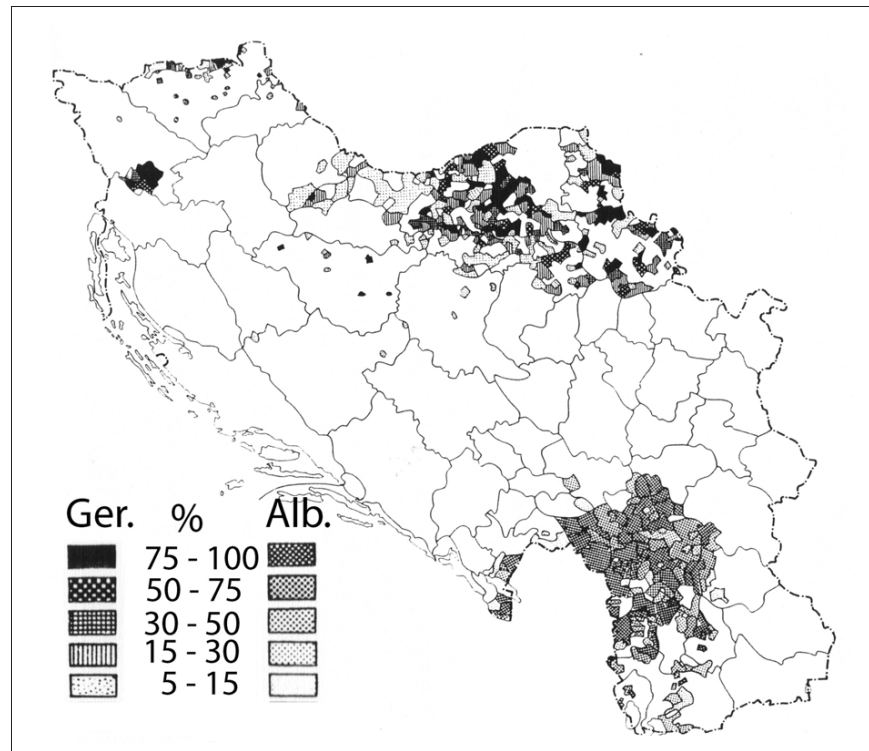

FIGURE 2 | Maps showing the distribution of non-Slavic ethnic groups within the former Yugoslavia (reprinted from Banac, 1984 with

permission from Cornell University Press). The left panel depicts regions where Germans (Ger.) and Albanians (Alb.) constitute from 5 to $100 \%$ of the population. The right panel depicts regions where Hungarians (Hun.) and

Turkish communities (Turk.) constitute 5-100\% of the population. In the left

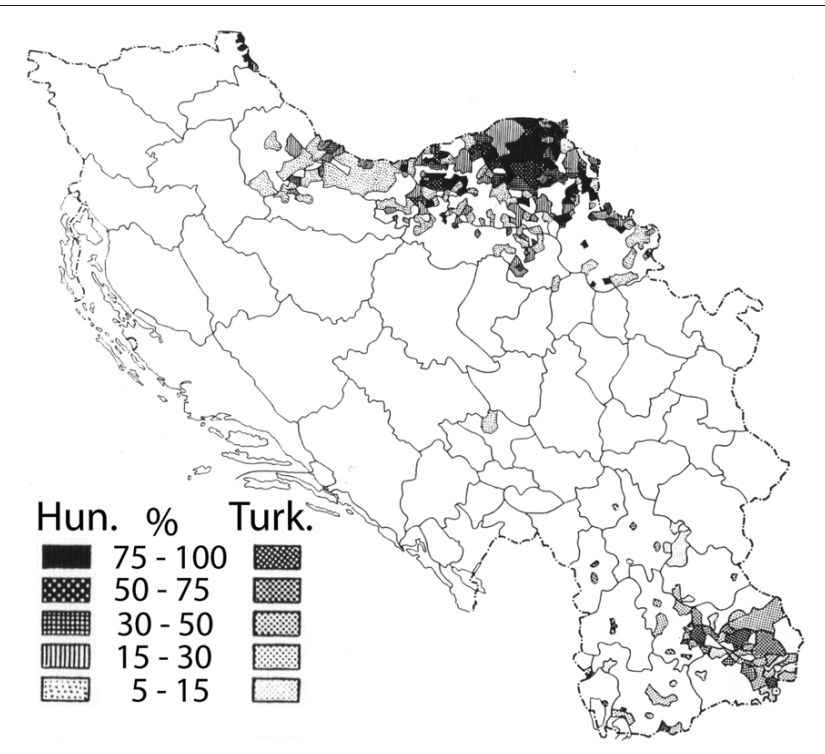

panel, the regions with significant Germanic communities lie exclusively within the top half of the map, and the regions with significant Albanian communities within the bottom half of the map. In the right panel, the regions with significant Hungarian communities lie within the top half of the map and the regions with significant Turkish communities within the bottom half of the map.
Rainfall." The percent of the country covered by a given isohyet interval was calculated, and the correction for population distribution was carried out by weighting the rainfall data by the population (in this case, as a percent of the total population of Ireland) in the towns lying within a given isohyet interval (only for those with 5,000 or more residents) for the appropriate census year, and assuming that the remaining land area exhibited a uniform population distribution. For the birth years 1921-1930, the census data was derived from the 1926 Ireland census; for the birth years 1931-1940, the census data was derived from the 1936 Ireland census; and for the birth years 1942-1945, the census data was derived from the 1946 Ireland census. The relationship between the population-corrected rain data and the 2 nd quarter season-of-birth data was then analyzed (Figure 4).

\section{STATISTICS}

Where mean values were calculated for rainfall and for rates of schizophrenia, standard deviations are not reported because no group-wise comparisons are made of the means. The program Linear regression was carried out using the program SigmaStat to test for correlation between mean rates of schizophrenia and mean values of rainfall, and the resulting $r$ value with the associated significance level ( $p$ value) is reported.

\section{GENE AND PEPTIDE SYMBOLS}

Alpha-MSH represents alpha-melanocyte-stimulating hormone. $M C 5 R$ represents melanocortin receptor-5 (for which alpha$\mathrm{MSH}$ is an agonist).

$\mathrm{MCH}$ represents melanin-concentrating-hormone.
MCHR1 represents melanin-concentrating-hormone receptor-1. MCHR2 represents melanin-concentrating-hormone receptor-2.

\section{RESULTS}

\section{THE FORMER YUGOSLAVIA}

A 16 year period of mean rainfall values (1925-1940) was considered representative of the pattern of rainfall normally experienced in Yugoslavia during the late 19th and early 20th centuries, according to the Yugoslavian Federal Hydrometerological Institute. A visual comparison of the weather map for the former Yugoslavia (Figure 1A) and a map of hospitalization rates for schizophrenia in the year 1930 (Figure 1B; after Crocetti et al., 1964 and Kuljzenko, 1933), revealed a striking similarity in the patterns. To quantify this apparent relationship, the mean annual rainfall was calculated for regions experiencing a given rate of hospitalization (Table 1). The correlation between the hospitalization rate for schizophrenia by place of birth (Crocetti et al., 1964; after Kuljzenko, 1933) and mean annual rainfall was determined to be $r=0.96$ $(p=0.008)$.

Crocetti et al. (1964), confirmed the patterns revealed in Kulzjenko's work for Croatia only. However, apart from the methodology of the patient ascertainment, an additional concern in a country as diverse as Yugoslavia is the confounding effect that different ethnic groups would pose for a disease that is thought to be partly genetic in origin. The bulk of the former Yugoslavia was composed primarily of Southern Slavs (Banac, 1984) who were either Christian or Muslim in religion. Small pockets of German, Hungarian, Albanian, and 


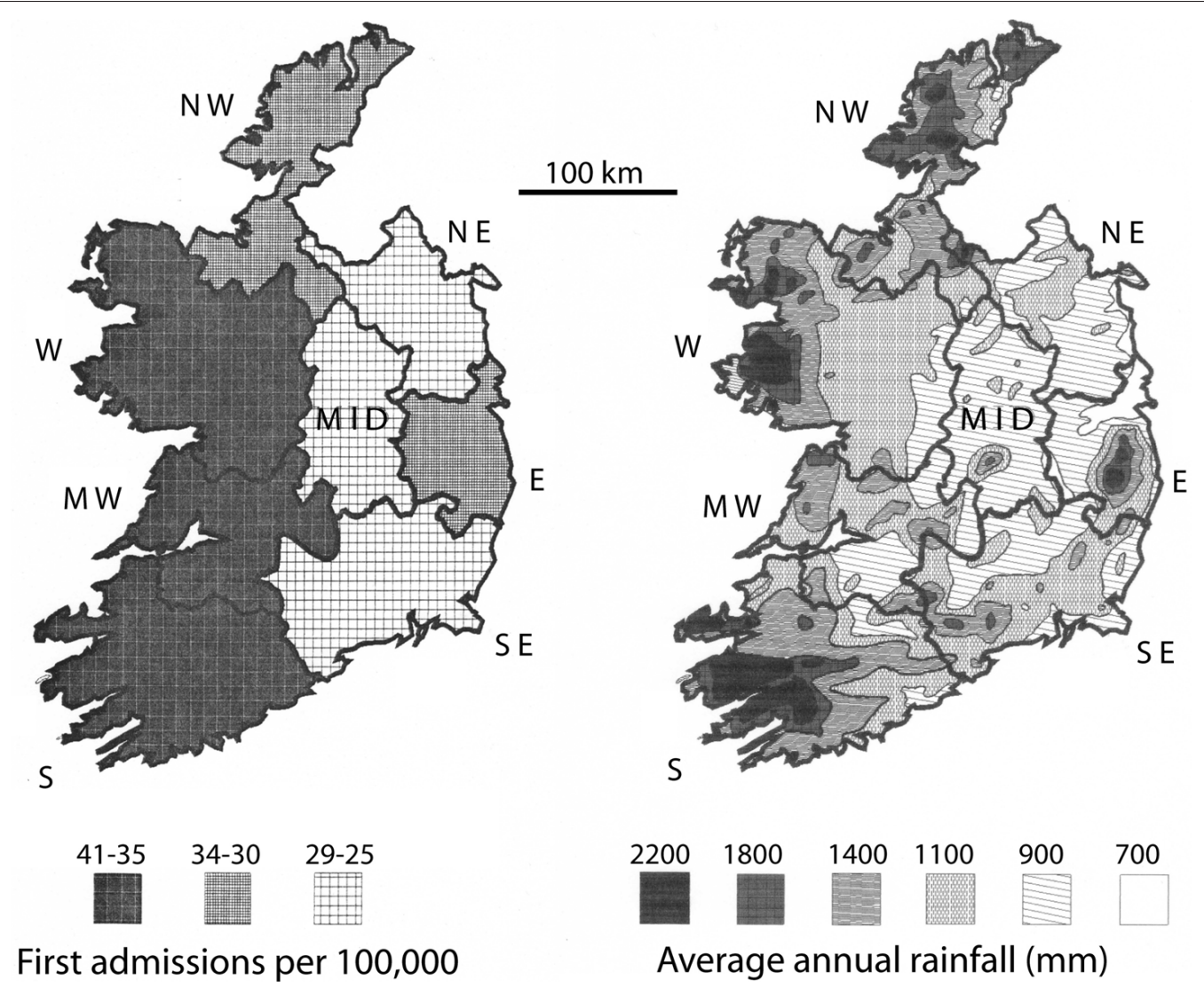

FIGURE 3 | Rates of schizophrenia 1st admissions (left panel) vs. annual rainfall (right panel) in Ireland. The 1 st admissions digital plot represent means of the yearly values in the outlined health catchment area (S, MW, W, NW, MID, NE, E, and SE), calculated for 1982-1991

from data published by the Health Research Board for Ireland (Activities

of Irish Psychiatric Hospitals and Units Dublin, Ireland). The annual rainfall digital plot (derived from the Irish Meteorological Service, Galway and Logue, 1984) represents means of the yearly totals for 1941-1970, which would have included the birth years for many of the 1st admission patients.

Turkish communities populated Yugoslavia in 1921 (Figure 2, after Banac, 1984). The most direct way to assess the impact of these ethnic groups was to remove from the analysis those regions in which non-Slavs were a high percentage of the population (Table 1, right column). Doing so had no effect on the direction of the correlation or the significance level $(r=$ 0.97; $p=0.008$ ); thus, ethnic differences do not appear to be responsible for the variation in rates of schizophrenia within Yugoslavia.

\section{IRELAND}

The data for schizophrenia in Ireland (Table 2) was derived from yearly publications of the Irish (Health Research Board, 1972-1994), which provide a variety of hospital statistics including first admission rates and comprehensive censuses taken for point hospitalization rates.

The hospital census data presented are for the year 1991. Mean first admission rates were calculated for a 10 year period (1982-1991, inclusive), selected to include a comprehensive census year (1991) and selected as a time of relative stability in terms of the grouping of the hospital reporting system. The exception is 1991, when: (1) in the NE, Cavan and Monaghan began to report as a unit, (2) in the $S$, a new psychiatric unit was formed in Tralee (joint reporting with the hospital in Killarney) and (3) in the NW, a new psychiatric unit in Letterkenny began reporting with St. Conal's (also in the town of Letterkenny). The latter event may be responsible for the apparent jump in first admission rates for the NW at that time. However, it is also possible that the 1991 jump in NW first admission rates reflects compensation for underreporting in the previous years, or is due to some other unknown factor.

For the number of patients hospitalized with schizophrenia, the correlation with mean annual rain is $r=0.52, p=$ 0.19 . For first admissions of schizophrenics, the correlation with mean annual rain is $r=0.65, p=0.084$. Thus, there is trend toward a correlation between rainfall and 1st admission rates of schizophrenia, but the trend does not reach statistical significance. One difference between Ireland and Yugoslavia was that both the range of rates for schizophrenia and the range of rainfall values were smaller in Ireland, 


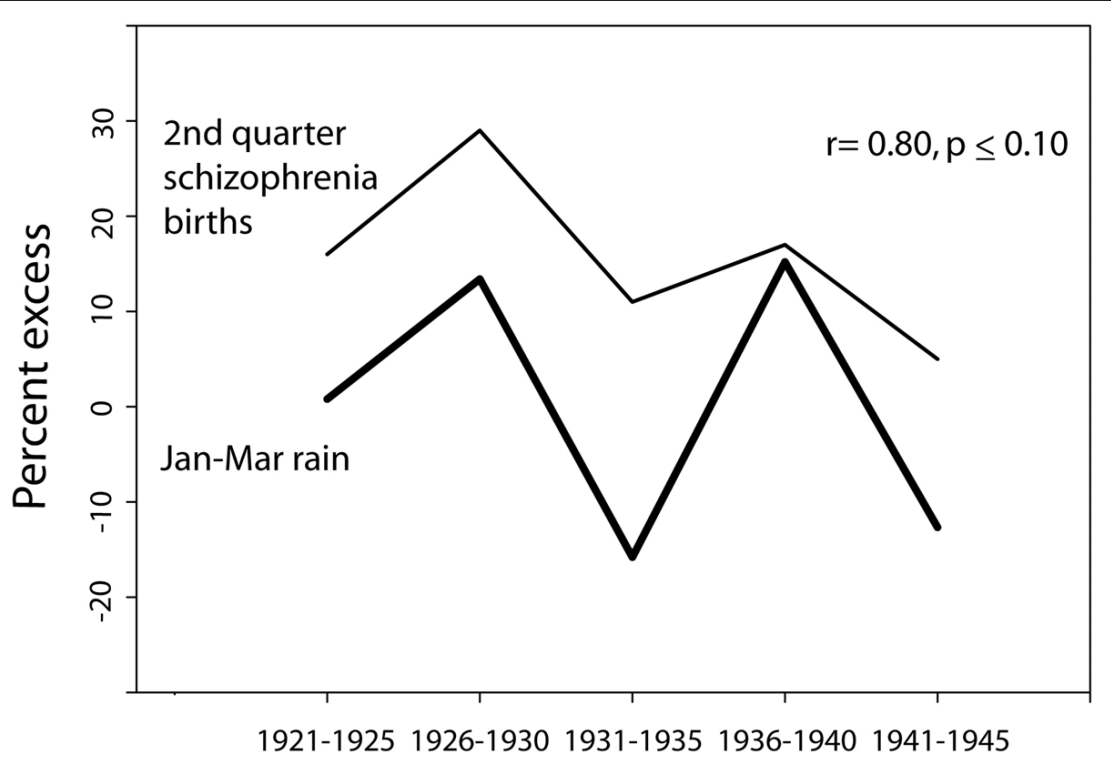

FIGURE 4 | The relationship between the percent excess (of average for weather stations in Ireland) of Jan-Mar rain and the percent excess of 2nd quarter schizophrenia births (as compared to the year-round quarterly average for 5 year period) for time periods spanning the years 1921-1945 (season-of-birth data derived from O'Hare et al., 1980). Note that Jan-Mar rain was not available from the series "British Rainfall" for the war year 1941, and thus the data point for the rainfall does not include 1941, though the schizophrenia data does include that year. To the extent that the weather in Ireland typically parallels the British Rainfall data mapped for Wales/West Midlands/Southwest England, the Jan-Mar rain would be expected to have been lower than average in 1941.
Table 1 | Rates of hospitalization and annual rainfall, Yugoslavia.

\begin{tabular}{lll}
\hline $\begin{array}{l}\text { Hospitalized } \\
\text { Schizoprenic Patients } \\
(\text { per 100,000) }\end{array}$ & $\begin{array}{l}\text { Mean annual rain } \\
(\mathbf{m m})^{\mathbf{b}}\end{array}$ & $\begin{array}{l}\text { Mean annual rain }(\mathbf{m m}) \\
\text { wi diverse ethnic } \\
\text { regions removed }\end{array}$ \\
\hline 200 & 1780 & 1780 \\
100 & 1470 & 1483 \\
50 & 906 & 917 \\
20 & 948 & 932 \\
0 & 764 & 766 \\
\hline
\end{tabular}

a Data obtained from Crocetti et al. (1964) for hospitalization rates in 1931.

${ }^{b}$ Data provided by the Yugoslavian Hydrometeorological Institute for the years $1925-1940$.

which decreases the power of the analysis. In addition, the scale of the data maps was more detailed for Yugoslavia than for Ireland. Thus, small scale variations in rainfall affecting a non-uniform distribution of population were more likely to confound the Irish data. For example, in County Donegal, the mean rainfall is $1455 \mathrm{~mm}$, but relatively small proportion of the population lives in regions with rainfall values of that magnitude.

Thus, to more accurately represent the amount of rainfall the average person in a catchment area experiences, the rain data was weighted by population distribution (Table 2; Materials and Methods). This analysis assumed a similar distribution of population existed during the time period when rainfall might have exerted an effect. The results show that if the rain data is weighted by the exposure of the most populous cities in a catchment area (Table 2), the 1st admissions for schizophrenia correlated significantly with mean annual rainfall $(r=0.71, p=0.047)$, and hospitalization rates showed a trend to correlate with mean annual rainfall $(r=0.65, p=0.082)$.

\section{SEASON OF BIRTH EFFECT IN IRELAND}

In 1980, O'Hare et al. published a study tracking the season of birth effect for births over a 35 year period in Ireland (19211955), reported for 5-year intervals. When compared to the expected number of births of individuals who would go on to develop schizophrenia, based on the total number of births in each quarter, the spring quarter showed a marked 29\% excess of future schizophrenics born in the 5 year period of time 19261930. The rainfall data available for that time period also showed some notable trends. To quote from the publication British Rainfall (which covered Ireland during those years), "1928 was the 6th successive year in which the rainfall over the British Isles as a whole was in excess of the average... we have to go back to the 'seventies to find so long a run of wet years.... A run of six consecutive years each with an appreciable excess is, however, unprecedented."

Of the years encompassed by the season of birth study, maps of rain data for Ireland were available from the British Meteorological Service spanning the years 1921-1945, with the exception of 1941. The mapped isohyet lines made possible the easy calculation of the surface area covered by particular rainfall patterns. Figure 4 illustrates the similarity in patterns between the national Jan-Mar quarterly excess in season of birth for schizophrenia in those years and the national excess or deficit in January to March rain for those years. 
Table 2 | Rates of hospitalization, first admissions and annual rainfall, Ireland.

\begin{tabular}{lllll}
\hline $\begin{array}{l}\text { Catchment } \\
\text { area }\end{array}$ & $\begin{array}{l}\text { Hospitalized Schizophrenic patients } \\
\text { (per } \mathbf{1 0 0 , 0 0 0} \text { gen. population) }\end{array}$ & $\begin{array}{l}\text { 1st Admissions for Schizophrenia } \\
\text { (per 100,000 gen. population) }\end{array}$ & $\begin{array}{l}\text { Mean annual } \\
\text { rain }^{\mathbf{b}} \text { (mm) }^{\text {(m) }}\end{array}$ & $\begin{array}{l}\text { Mean annual rain weighted } \\
\text { by pop. exposed }\end{array}$ \\
\hline W & 166.6 & 34.7 & 1274 & 1248 \\
MW & 122.4 & 40.7 & 1134 & 1134 \\
S & 124.4 & 37.5 & 1441 & 1360 \\
NW & 102.0 & 32.7 & 1378 & 1317 \\
SE & 99.0 & 29.4 & 1063 & 1013 \\
MID & 103.4 & 27.8 & 935 & 935 \\
E & 65.9 & 30.5 & 1045 & 933 \\
NE & 84.4 & 24.6 & 986 & 912 \\
\hline
\end{tabular}

${ }^{a}$ Hospital census in 1991 (Health Research Board, Ireland).

${ }^{b}$ Mean annual rain in Ireland for the years 1941-1970.

${ }^{c}$ Population based on the 1986 census for Ireland.

When the annual rain data was weighted by the underlying population distribution affected by each particular rain pattern, the degree of correlation with season of birth effect was high $(r=0.80)$ and trended toward significance $(p \leq$ $0.10)$.

The possibility of a correlation was explored between 1st admissions for schizophrenia (Table 2) and degree of season-ofbirth effect as reported by O'Hare et al. (1980), but no correlation was found $(r=0.0034, p=0.994)$.

\section{DISCUSSION}

The data assembled and analyzed for this study are entirely consistent with a role for photic cues in human development and behavior, in this case behaviors as pronounced as those seen in schizophrenia. The observed patterns could reflect differences in genetic traits of the populations, gene-environment interactions specific for certain genotypes in certain environments, and/or phenotypic plasticity that can occur for all genotypes.

The season-of-birth pattern strongly supports work by Messias et al. $(2001,2006)$ who demonstrated a remarkably similar finding for schizophrenia season-of-birth in Brazil, where the main variation in seasonal weather is limited to a January through March rainy season. In those studies, a significant association was found between rainfall during a given month and the number of individuals with schizophrenia with birth dates 3 months later. Similarly, McGrath et al. (2002) found a significant association between variations in perinatal sunshine duration and the season of birth effect in schizophrenia. Furthermore, a recent report demonstrates an equivalently strong season-of-birth effect in multiple sclerosis with peaks in April and May and in parallel with schizophrenia (Torrey et al., 1997; Davies et al., 2003), deficits in births of future multiple sclerosis patients during October and November (Dobson et al., 2013), a finding the authors attribute to variations in sunlight during gestation and to the resulting variations in vitamin $\mathrm{D}$ availability.

Although the association between schizophrenia and the influence of heavy rainfall on photic input represents a potentially important avenue of research, this study outcome does not preclude the involvement of other environmental variables influenced by rainfall. The critical variable that rainfall represents could also include lower temperature (although rainfall does not always correspond to lower temperature) and infectious disease (spread more easily when people must spend more time indoors). Others have shown (Hare and Moran, 1981; Kinney et al., 1993) that the degree of the season of birth effect for schizophrenia was proportional to the severity of weather near birth, but in that case an association was found with cold temperatures during the last trimester. Similarly, Kendell and Adams found an association with low temperature 6 months prior to birth (1991) and Gupta and Murray (1992) report an association between environmental temperature and the incidence and outcome of schizophrenia. Data presented here for Ireland would argue against infections as underlying the association between rainfall and schizophrenia because the rates for 1st admissions are highest in the rural south and west, where infectious disease spread through crowded indoor quarters was less likely than in the eastern urban areas. Furthermore, an aspect of the season-of-birth effect that has been somewhat overlooked (Torrey et al., 1997) is the consistent deficit in schizophrenic births occurring in the late summer and early fall, particularly evident at higher latitudes (Davies et al., 2003). The excess/deficit finding is more compatible with cyclic, seasonal decreases and increases in light than with spread of any single infectious agent. Despite the fact that peaks in specific infectious diseases certainly do occur for particular months, those peak months are not usually matched by a large deficit in a couple of months at the opposite end of the year.

\section{THE PROCESSING OF PHOTIC STIMULI IN ANIMALS}

The availability of sunlight is undoubtedly one of the most important environmental factors that influence survival. Animal physiology is accordingly geared to respond to changes in both the sunlight intensity and duration, i.e., photoperiod. Photoperiod is defined as the length of time a given species perceives photic stimuli during the day and is obviously specific to the season of the year and to latitude. The response of the pineal to changes in the photoperiod involves regulation of melatonin production, a hormone integrally involved in setting the circadian clock (Bartness and Goldman, 1989). From the survival standpoint, a change in photoperiod is more informative for long term conditions in the postnatal environment than is temperature and for most animals, 
the photoperiod determines whether reproduction occurs or not. In species that can reproduce at different times of the year or year round, the effects are more subtle and relate to postnatal hormonal levels, circadian entrainment and somatic measures of development.

Photoperiod is sensed via projections along the retinohypothalamic pathway to the pineal gland, operating as a step function (Prendergast and Zucker, 2012). Below a given intensity range, there is no response and above that range, the response is constant until the light level drops again. Suppression of melatonin synthesis in the pineal progresses in the early dawn with the first faint signal that the sun will be rising soon. The sensitivity of response is species specific, such that 1 lux is reported to be sufficient to significantly suppress melatonin synthesis in the Syrian hamster (Brainard et al., 1982). But at 119 lux, a level comparable to a clear summer sunrise at northern temperate latitudes (Didrikas and Hansson, 2009), the human pineal will generally have downregulated melatonin production by only $50 \%$ (Zeitzer et al., 2000) with full suppression by 2500 lux (Coetzee et al., 1989; Arendt, 1998).

The relevant cues provided by photoperiod can be delivered both pre-and postnatally (e.g., voles, Lee and Zucker, 1988; collared lemmings, Nagy et al., 1993; Siberian hamsters, Stetson et al., 1986; Shaw and Goldman, 1995; and Prendergast et al., 1996; sheep, Ebling et al., 1989; and red deer, Adam et al., 1992). Perhaps of greatest importance to the behavior of interest, postnatal dopaminergic tone is influenced by the photoperiod experienced in utero. Dopamine controls prolactin levels, the most obvious expression of which is coat thickness and/or color in animals (Hoffman, 1978; Lee and Zucker, 1988). A short photoperiod upregulates hypothalamic dopaminergic activity, inhibiting prolactin release and initiating the development of a winter coat. Postnatal administration of dopaminergic antagonists can block development of the winter coat, whereas dopaminergic agonists promote a winter coat (Badura and Goldman, 1992; Gower et al., 1993). To what extent such striking gene-environment interactions are controlled by epigenetic changes is not known for mammals, though epigenetic modifications in response to photoperiod have been well documented in plants (Kim and Sung, 2010). Many photoperiod effects controlled by the pineal are encoded by the peptide hormone alpha-MSH (Kastin et al., 1967a,b), which is upregulated in response to long photoperiods, predominantly expressed in the cells of the intermediate pituitary and centrally, in the arcuate nucleus of the hypothalamus (O’Donohue and Dorsa, 1982; Hadley, 1984; Khachaturian et al., 1985).

The timing of photoperiod effects relevant to behavior could theoretically include events as early as the time of conception. As proposed by Jongbloet (1975) and Pallast et al. (1994), increased light duration during the summer could lead to release of ova that are over-mature and predisposed to defective development. However, the pre-natal critical period for the major photic effects on animal behavior and development probably lies closer to the equivalent of the last trimester in humans (Hoffman, 1978; Reppert, 1985; Stetson et al., 1986; Weaver et al., 1987; Lee and Zucker, 1988; Nagy et al., 1993; Bellavía et al., 2006; Butler et al., 2007). The types of behaviors influenced by photoperiod are species and gender dependent, and include the more bold behaviors observed for female Brazilian guinea pigs born in spring, whereas males do not show such clear differences (Guenther and Trillmich, 2013). Other behavioral effects are induced by a short postnatal photoperiod and include elevated measures of anxiety and depression seen in adult Siberian hamsters, collared lemmings, and nocturnal rodents, as well as reductions in learning and memory capacity seen in male white-footed mice (as reviewed by Walton et al., 2011).

In addition to photoperiod response, there are responses to sunlight intensity, some of which are not mediated by the pineal. In contrast to most other animals, humans have a large cutaneous surface area that is responds to sunlight by proportional (not stepwise) adjustments to sunlight intensity for both vitamin D (Chen et al., 2007) and melanotropin production (Farooqui et al., 1993; Chakraborty et al., 1996; Hiramoto et al., 2003).

Although sunlight-induced vitamin D is not an important source of vitamin D for lower animals, it has been shown that prenatal dietary vitamin $\mathrm{D}$ in Sprague-Dawley rats has significant effects on postnatal anxiety and social behaviors (Pan et al., 2013).

Therefore, at issue is which of these photic response processes might relate to observations that rates of schizophrenia vary with latitude, season of birth and rainfall? Photoperiod could certainly underlie a phenotypic response to latitude and season, but unlike processes modulated by sunlight intensity, it is not affected by weather. Rather, entraining the photoperiod is strongly tied to the calendar date and is seemingly independent of year to year fluctuations in precipitation or cloud cover. One of the most informative observational studies in this regard involved the coat color change in the snowshoe hare, in which it was demonstrated that a year with an unusually heavy spring snowfall pattern (and hence, cloud cover) did not change the date at which coat color changed from white to brown, leaving some animals brown against a white background (Mills et al., 2013).

Although weather does not alter photoperiod entrainment by the pineal, there may nevertheless be neurophysiological consequences resulting from weather changing the rate and the degree to which pineal melatonin is suppressed during the daylight hours. Thus, even the snowshoe hare study described above revealed a possible role for sunlight intensity, in that the hares began the development of a brown coat at the correct calendar time in a snowy spring but completed the transition from white to brown at a slower rate than during a less snowy spring (Mills et al., 2013). A pineal-mediated effect exerted by low light intensity occurring during a relatively long photoperiod has also been directly examined in birds, for which Kumar et al. (2007) found a delay in reproduction, explaining why in wild bird populations, heavy rainfall can similarly delay reproduction (reviewed by Small and Moore, 2009). The magnitude of the impact of a heavy rainy season on sunlight intensity has been quantified for the Tibetan plateau, where consistently heavy rain in summer decreases both the daylight duration and the sunrise to sunset light levels equivalent to those seen in spring (Liu et al., 2012). For humans, the effect of rain on photic input is further complicated by the need to be indoors during heavy rain and for much of the time period covered by the present study, the populations in question would have had limited alternatives for indoor lighting. Even with 
optimal "daylighting" strategies seen now in modern building design, the maximum indoor sunlight levels achieved midday on a clear Stockholm day in December, for example, barely reaches above 200 lux (De Carli and Valeria De Giuli, 2009), with values less than $\sim 50$ lux for at least some of the working hours after sunrise but before sunset. Cloud cover and rainfall could be expected to further decrease those levels by 70 and $83 \%$, respectively (Luccini et al., 2003), depending on the thickness of cloud cover and the intensity of rain (Calbo et al., 2005).

With respect to the possible role of sunlight intensity in behavioral phenotypes, it has been proposed that cutaneous vitamin $\mathrm{D}$ generation may be involved in gestational effects that modulate the eventual development of schizophrenia (McGrath and Welham, 1999). In addition, other hormones of interest are produced in the skin in response to the intensity of the natural spectrum, including the melanotropin alpha-MSH (Farooqui et al., 1993; Lin and Fisher, 2007). Any matching CNS elevations of alpha-MSH via cues from the pineal would be expected to have important effects on learning and memory (LaHoste et al., 1980; Beckwith et al., 1989; Machado et al., 2010; Shen et al., 2013), the processing of sensory information (Miller et al., 1993) and feeding behaviors (Nahon, 1994, 2006).

\section{PHENOTYPIC PLASTICITY, GENETIC TRAITS AND GENE-ENVIRONMENT INTERACTIONS}

The season-of-birth effect is clearly an example of phenotypic plasticity but it also offers a window into forces that may have selected for genetic change. There are many examples in animal evolutionary history of phenotypic plasticity giving way to related "hardwired" traits (Van Buskirk et al., 1997), a phenomenon that some evolutionary biologists term the "flexible stem hypothesis" (Wund et al., 2008; Tebbich et al., 2010; Muschick et al., 2011). The physiology of light-responsive genes normally seen with seasonal environmental changes in light levels would also be engaged when year round light levels become different, as happens for individuals migrating from southern to northern climates. But over evolutionary time, the more completely adapted physiologies will exhibit permanent genetic traits that have been selected for by the new environment. A potentially relevant example would be the phenotypic plasticity identified in monozygotic twins discordant for bipolar disorder, who carry epigenetic methylation differences in the receptor for the functional antagonist of alpha$\mathrm{MSH}$, the melanotropin receptor known as GPR24 or MCHR1 (Dempster et al., 2011). Yet, hardwired differences in that gene were also selected for and have been found to be associated with bipolar disorder across unrelated individuals (Miller et al., 2009).

The need for vitamin D may have played an important role in selecting for polymorphisms in a variety of light-responsive genes, including the melanotropins. Any genetic polymorphism that enhances the ability of vitamin $\mathrm{D}$ to be generated from light would have been advantageous in low-light regimes, except when vitamin D was easily obtained from the diet. It is well known that a lack of vitamin D causes rickets, which would have had a negative impact the ability to perform the physical work necessary to survive in historical times, but more importantly, frequently caused fatal outcomes during delivery because of the improper configuration of pelvis in severe rickets
(Harrison, 1966; Cruickshank, 1967; Konje and Ladipo, 2000). Genetic polymorphisms that increase risk of fatal outcomes prior to successful reproduction are under intense negative selective pressure, readily apparent within a few generations (reviewed by Miller, 2009). In such a manner, certain polymorphisms in melanotropin genes may have become more prevalent in lowlight environments if they positively affected the natural synthesis of vitamin $\mathrm{D}$ by reducing the synthesis and sequestration of melanin (Valverde et al., 1995). The evolutionary trade-off in this case would have been an increased prevalence of polymorphisms in melanotropin genes (MCHR1, MC5R, MCHR2) of risk for schizophrenia (Severinsen et al., 2006; Miller et al., 2009; Demontis et al., 2012).

Although no genetic associations between vitamin-D receptors or enzymes involved in its formation or degradation have yet been identified for schizophrenia, that outcome does not necessarily mean that vitamin D is without effect in modifying the phenotypic plasticity that is obviously present in the disease. An interaction between vitamin $\mathrm{D}$ and the melanotropin system during development has been demonstrated by Eyles et al. (2007) who found that prenatal vitamin $\mathrm{D}$ deficiency in rodents leads to elevations in the functional antagonist of alpha-MSH, the melanotropic peptide $\mathrm{MCH}$. However, McGrath and colleagues have also shown that the relationship between vitamin $\mathrm{D}$ in gestation and subsequent schizophrenia may be complex, in that those with low maternal vitamin $\mathrm{D}$ are at increased risk of bearing offspring who become schizophrenic as are those with overly high vitamin D (McGrath et al., 2010a).

What might be the relative impact of phenotypic plasticity vs. genetic traits of risk? For schizophrenia, the calculations show that the impact of the season-of-birth effect is not minor but rather roughly equivalent to that of family history of disease (Mortensen et al., 1999). For the northern hemisphere, the population attributable risk caused by a late winter/spring birth is on average 3.3\% (Davies et al., 2003) but ranges to $10.5 \%$ in some locales (Mortensen et al., 1999), whereas the populationattributable risk if a parent or sibling was schizophrenic was 5.5\% in the Mortensen et al. study (1999).

The season-of-birth effect could also be viewed as an example of gene-environment interaction because the effect is not uniform across the population; rather, it is reported to be greatest in those without a family history of the disease (O'Callaghan et al., 1991). Similarly, gene-environment interactions may underlie the remarkably increased risk of schizophrenia for immigrant populations from Afro-Caribbean countries who have relocated to the U.K. (McGovern and Cope, 1987; Wessely et al., 1991; Harrison et al., 1997; Sharpley et al., 2001; Coid et al., 2008), as compared to the incidence of schizophrenia in their native lands (Hickling and Rodgers-Johnson, 1995; Bhugra et al., 1996; Mahy et al., 1999) and as compared to immigrants from other countries (Coid et al., 2008). Barring the unlikely possibility of preferential migration of the most genetically at-risk individuals, their increased predisposition to schizophrenia in the U.K. must be triggered by some factor in the environment interacting with particular aspects of their genetic background. The model put forth in this paper would presume that the culpable environmental factor is related to lower light levels in northerly climates, although 
the effect of the stress of immigrating to a different culture cannot easily be discounted, as discussed by Coid et al. (2008). In addition, rates of usage of illicit drugs may be higher amongst Afro-Caribbeans immigrants, particularly of concern if the drug of choice is cannabis (McGuire et al., 1995; Moore et al., 2007; Arendt et al., 2008; Di Forti et al., 2009; McGrath et al., 2010b). The rate of cannabis use in the Afro-Caribbean immigrant population may be somewhat higher vs. long term residents of the U.K. (Harvey et al., 1990) but may not be higher than rates in their home countries which have been reported to be already quite high (reviewed by Sugarman and Craufurd, 1994; Maharajh and Konings, 2005). However, other investigators found no elevation in drug use in Afro-Caribbeans in the U.K. as compared to non-immigrants (Cochrane and Bal, 1989; McGuire et al., 1995; reviewed by Coid et al., 2008).

Obviously, two of the major light-responsive physiological systems that would be strongly affected in Afro-Caribbean immigrants to the U.K. would be UV-induced vitamin D and the melanotropins. UV-induced vitamin-D would be expected to be particularly low for these individuals (Ford et al., 2006; Chen et al., 2007), as would the stimulation of the light-responsive melanotropin system in the climatic regime found in the U.K., since skin pigment would be expected to lessen the responsiveness of alpha-MSH levels to the relatively low level of UV radiation found there (Holzmann et al., 1983; Altmeyer et al., 1986; Chakraborty et al., 1996). It is noteworthy that the schizophrenia risk is higher for the second generation than the first (McGovern and Cope, 1987; Coid et al., 2008), suggestive of epigenetic effects during growth and development.

There is reason to believe that gene-environment interactions may also underlie certain of the genetic associations with schizophrenia identified in the melanotropin genes (Severinsen et al., 2006; Miller et al., 2009; Demontis et al., 2012). When evaluating genetic association studies, it must be kept in mind that they occur in particular environments. Thus, the resulting associations can be for genetic polymorphisms which exhibit strong interactions with that environment as well as those that don't. Based on the "flexible stem" hypothesis, the expectation would be that if an association was found for an ancestral polymorphism of relatively lower prevalence in the study environment than in the ancestral environment, this outcome might be indicative of a gene-environment interaction causing disease in the study environment. The ancestral polymorphism would represent the "flexible stem" form of the gene, a form which eventually was selected against. Such may be the case for the association between schizophrenia and a coding change in the MC5R gene identified in a temperate-zone genetic association study (Miller et al., 2009). Against a background of other risk genes (TDO2 and MCHR2), the MC5R polymorphism of risk (rs2236700) was unexpectedly found to be the ancestral allele, an allele roughly twice as prevalent in the Yoruba peoples of Nigeria as in Caucasians represented by the CEPH collection (HapMap, www.hapmap.org). Based on the fact that meta-analyses showed a higher incidence of schizophrenia with higher latitude (Saha et al., 2006), it would not be expected that an allele more prevalent in Nigeria would be associated with a greater risk of disease. But the key fact to remember is that in the genetic association study of interest (Miller et al., 2009) the disease was diagnosed in people living in another climate, i.e., in temperate zone latitudes.

Thus, the association of MC5R with schizophrenia could theoretically represent a gene-environment interaction relevant to the outcome seen for Afro-Caribbean peoples migrating to the U.K. $M C 5 R$ is a receptor for alpha-MSH which, as described above, is one of the light-responsive hormones elevated during long-day photoperiods and when light levels are more intense. The function of its $M C 5 R$ receptor is diverse, ranging from stimulation of sebaceous glands (Eisinger et al., 2011) to immunoregulation (Taherzadeh et al., 1999; Taylor and Namba, 2001), to behavioral effects that include modulation of aggression (Morgan et al., 2004). Because MC5R's association with schizophrenia was identified against the genetic background of a risk allele for the immunomodulatory kynurenine pathway enzyme TDO2 (Miller et al., 2009), it is most likely that the key action in this case would be the reported inhibition of IFN $\gamma$ expression by MC5R (Taylor and Namba, 2001). IFN $\gamma$ stimulates the expression of IDO (Taylor and Feng, 1991), one of the other enzymes responsible for activating the immunomodulatory, and pigment-generating kynurenine pathway. Kynurenine pathway activation has been demonstrated in several studies of schizophrenia (reviewed by Schwarcz et al., 2012). Although the necessary studies have not yet been done to determine the functional effect of the risk allele of $M C 5 R$, if it were to be the case that it coded for a less sensitive version of the $M C 5 R$ receptor, the result would be increased activation of the kynurenine pathway, further augmenting pathway flux in low light environments where the MC5R agonist alpha-MSH is already low.

\section{OTHER EVIDENCE FOR THE INVOLVEMENT OF THE PHYSIOLOGY OF PHOTIC RESPONSE IN THE EXPRESSION OF SCHIZOPHRENIA}

Additional evidence for light-responsive melanotropin involvement can be found in an alternative mechanism of action proposed for antipsychotic drugs (Miller, 2013), based on the observed reaction between antipsychotic drugs and a neurotoxic catecholamine breakdown product to form the more innocuous pigment polymer, melanin. Consistent with this outcome, the melanotropin alpha-MSH, which enhances melanin formation and its sequestration, has been shown to normalize sensory gating in an auditory model of a schizophrenia endophenotype (Miller et al., 1993). In contrast, the melanotropin that inhibits the formation of melanin and its subsequent sequestration $(M C H)$, inhibits effective sensory gating (Miller et al., 1993; Chung et al., 2011). Furthermore, nutritional imbalances that perturb melanogenesis can also elicit symptoms of psychosis (reviewed by Miller, 2011).

\section{CONCLUSIONS}

The correlations between epidemiological data and light levels are strong for schizophrenia, and should not be ignored in the search for means of lowering the incidence of this major mental disorder. The need for vitamin D may have affected not only gene frequencies of relevance to schizophrenia but may also have modulated gene-environment interactions that can occur in differing light regimes. We modern humans tend to downplay the effect of 
environment in controlling our health and well-being, particularly in regards to an environmental force such as light that can be replaced by an artificial source. Yet it would be unwise to discount the importance of natural light, particularly when our reliance on it was so high during our recent evolutionary past.

\section{LIMITATIONS OF THE STUDY}

The methods of ascertainment of cases in the data set for the former Yugoslavia cannot be effectively validated. Much criticism of diagnostic methodology has been directed toward many studies of schizophrenia, and the current study is particularly vulnerable to such critiques. Despite the fact that the methods employed in Ireland have been overseen and well-supervised

\section{REFERENCES}

Adam, C. L., Kyle, C. E., and Young, P. (1992). Influence of prenatal photoperiod on postnatal prolactin secretion in the red deer (Cervus elaphus). J. Reprod. Fertil. 95, 959-964. doi: 10.1530/jrf.0.0950959

Altmeyer, P., Stöhr, L., Holzmann, H. (1986). Seasonal rhythm of the plasma level of alpha-melanocyte stimulating hormone. J. Invest. Dermatol. 86, 454-456. doi: 10.1111/1523-1747.ep12285798

Arendt, J. (1998). Melatonin and the pineal gland: influence on mammalian seasonal and circadian physiology. Rev. Reprod. 3, 13-22. doi: 10.1530/ror.0.0030013

Arendt, M., Mortensen, P. B., Rosenberg, R., Pedersen, C. B., and Waltoft, B. L. (2008). Familial predisposition for psychiatric disorder: comparison of subjects treated for cannabis-induced psychosis and schizophrenia. Arch. Gen. Psychiatry 65, 1269-1274. doi: 10.1001/archpsyc.65.11.1269

Badura, L. L., and Goldman, B. D. (1992). Prolactin-dependent seasonal changes in pelage: role of the pineal gland and dopamine. J. Exp. Zool. 261, 27-33. doi: 10.1002/jez.1402610105

Banac, I. (1984). The National Question in Yugoslavia: Origins, History, Politics. Ithaca, NY: Cornell University Press.

Bartness, T. J., and Goldman, B. D. (1989). Mammalian pineal melatonin: a clock for all seasons. Experientia 45, 939-945. doi: 10.1007/BF01953051

Beckwith, B. E., Tinius, T. P., Hruby, V. J., al-Obeidi, F., Sawyer, T. K., and Affholter, J. A. (1989). The effects of structure-conformation modifications of melanotropin analogs on learning and memory: D-amino acid substituted linear and cyclic analogs. Peptides 10, 361-368. doi: 10.1016/0196-9781(89)90044-2

Bellavía, S. L., Carpentieri, A. R., Vaqué, A. M., Macchione, A. F., and Vermouth, N. T. (2006). Pup circadian rhythm entrainment-effect of maternal ganglionectomy or pinealectomy. Physiol. Behav. 89, 342-349. doi: 10.1016/j.physbeh.2006.06.018

Bhugra, D., Hilwig, M., Hossein, B., Marceau, H., Neehall, J., Leff, J., et al. (1996). First-contact incidence rates of schizophrenia in Trinidad and one-year follow-up. Br. J. Psychiatry 169, 587-592. doi: 10.1192/bjp.169.5.587

Brainard, G. C., Richardson, B. A., Petterborg, L. J., and Reiter, R. J. (1982). The effect of different light intensities on pineal melatonin content. Brain Res. 233, 75-81. doi: 10.1016/0006-8993(82)90931-3

British Meteorological Service. (19211946). British Rainfall. London: His Majesty's Stationery Office, Jas. Truscott and Son, Ltd.

Burgaz, A., Akesson, A., Oster, A., Michaëlsson, K., and Wolk, A. (2007). Associations of diet, supplement use, and ultraviolet B radiation exposure with vitamin $\mathrm{D}$ status in Swedish women during winter. Am. J. Clin. Nutr. 86, 1399-1404.

Butler, M. P., Turner, K. W., Park, J. H., Butler, J. P., Trumbull, J. J., Dunn, S. P., et al. (2007). Simulated natural day lengths synchronize seasonal rhythms of asynchronously born male Siberian hamsters. Am. J. Physiol. Regul. Integr. Comp. Physiol. 293, R402-R412. doi: 10.1152/ajpregu.00146.2007

Calbo, J., Pages, D., and Gonzalez, J. A. (2005). Empirical studies of cloud effects on UV radiation: a review. Rev. Geophys. 43, 1-28. doi: 10.1029/2004RG000155

by the Health Research Board of Ireland, their methodology undoubtedly changed over time. Furthermore, no correction for potentially confounding variables such as demographics of the local population, drug use or obstetrical complications was possible.

\section{ACKNOWLEDGMENTS}

I would like to gratefully acknowledge the help of the Irish Health Research Board, in particular Eva Mulleady, an employee at the time, as well as the kind assistance of the Irish Meteorological Service, Dublin; J.J. Logue of the Irish Meteorological Service, Galway; Danica Spasova of the former Yugoslavian Federal Hydrometeorological Institute and Momcilo Markus, formerly of the U.S. National Oceanic and Atmospheric Administration.

Chakraborty, A. K., Funasaka, Y., Slominski, A., Ermak, G., Hwang, J., Pawelek, J. M., et al. (1996). Production and release of proopiomelanocortin (POMC) derived peptides by human melanocytes and keratinocytes in culture: regulation by ultraviolet B. Biochim. Biophys. Acta. 1313, 130-138. doi: 10.1016/0167-4889(96)00063-8

Chen, T. C., Chimeh, F., Lu, Z., Mathieu, J., Person, K. S., Zhang, A., et al. (2007). Factors that influence the cutaneous synthesis and dietary sources of vitamin D. Arch. Biochem. Biophys. 460, 213-217. doi: 10.1016/j.abb.2006.12.017

Chung, S., Verheij, M. M., Hesseling, P., van Vugt, R. W., Buell, M., Belluzzi, J. D., et al. (2011). The melanin-concentrating hormone $(\mathrm{MCH})$ system modulates behaviors associated with psychiatric disorders. PLoS ONE 6:e19286. doi: 10.1371/journal.pone.0019286

Cochrane, R., and Bal, S. S. (1989). Mental hospital admission rates of immigrants to England: a comparison of 1971 and 1981. Soc. Psychiatry Psychiatr. Epidemiol. 24, 2-11. doi: 10.1007/BF01788193

Coetzee, J. A., Theron, J. J., and van der Merwe, C. A. (1989). Consecutive melatonin circadian rhythms in normal volunteers. S. Afr. Med. J. 75, 163-165.

Coid, J. W., Kirkbride, J. B., Barker, D., Cowden, F., Stamps, R., Yang, M., et al. (2008). Raised incidence rates of all psychoses among migrant groups: findings from the East London first episode psychosis study. Arch. Gen. Psychiatry 65, 1250-1258. doi: 10.1001/archpsyc.65.11.1250

Crocetti, G. M., Kulcar, Z., Kesic, B., and Lemkau, P. V. (1964). Differential rates of schizophrenia in Croatia, Yugoslavia. Am. J.
Public Health 54, 196-206. doi: 10.2105/AJPH.54.2.196

Cruickshank, E. K. (1967). "Nutrition in pregnancy and lactation," in Obstetrics and Gynaecology in the Tropics and Developing Countries, eds. J. B. Lawson and D. D. Stewart (London: Edward Arnold Press), 11-28.

Dalén, P. (1990). Does age incidence explain all season-of-birth effects in the literature? Schizophr. Bull. 16, 11-12. discussion: 17-28.

Davies, G., Welham, J., Chant, D., Torrey, E. F., McGrath, J. (2003). A systematic review and meta-analysis of Northern Hemisphere season of birth studies in schizophrenia. Schizophr. Bull. 29, 587-593. doi: 10.1093/oxfordjournals.schbul.a007030

De Carli, M. D., and Valeria De Giuli, V. (2009). "Optimization of daylight in buildings to save energy and to improve visual comfort: analysis in different latitudes," in 11th International IBPSA Conference (Glasgow: IBPSA), 1797-1805.

Demontis, D., Nyegaard, M., Christensen, J. H., Severinsen, J., Hedemand, A., Hansen, T., et al. (2012). The gene encoding the melanin-concentrating hormone receptor 1 is associated with schizophrenia in a Danish case-control sample. Psychiatr. Genet. 22, 62-69. doi: 10.1097/YPG.0b013e32834dc424

Dempster, E. L., Pidsley, R., Schalkwyk, L. C., Owens, S., Georgiades, A., Kane, F., et al. (2011). Diseaseassociated epigenetic changes in monozygotic twins discordant for schizophrenia and bipolar disorder. Hum. Mol. Genet. 20, 4786-4796. doi: 10.1093/hmg/ddr416

Didrikas, T., and Hansson, S. (2009). Effects of light intensity on activity and pelagic dispersion of 
fish: studies with a seabedmounted echosounder. ICES J. Marine Sci. 66, 388-395. doi: 10.1093/icesjms/fsn 173

Di Forti, M., Morgan, C., Dazzan, P., Pariante, C., Mondelli, V., Marques, T. R., et al. (2009). High-potency cannabis and the risk of psychosis. Br. J. Psychiatry 195, 488-491. doi: 10.1192/bjp.bp.109.064220

Dobson, R., Giovannoni, G., and Ramagopala, S. (2013). The month of birth effect in multiple sclerosis: systematic review, meta-analysis and effect of latitude. J. Neurol. Neurosurg. Psychiatry 84, 427-432. doi: 10.1136/jnnp-2012-303934

Donnchadha, G. O., Callaghan, T. O., and Niland, C. (2002). A Socio-economic Study of Fisheries in Counties Cork, Donegal, Kerry and Galway, Project 97.IR.MR.008. Dublin: The Marine Institute.

Ebling, F. J., Wood, R. I., Suttie, J. M., Adel, T. E., and Foster, D. L. (1989). Prenatal photoperiod influences neonatal prolactin secretion in the sheep. Endocrinology 125, 384-391. doi: 10.1210/endo-125-1384

Eisinger, M., Li, W. H., Anthonavage, M., Pappas, A., Zhang, L., Rossetti, D., et al. (2011). A melanocortin receptor 1 and 5 antagonist inhibits sebaceous gland differentiation and the production of sebum-specific lipids. J. Dermatol. Sci. 63, 23-32. doi: 10.1016/j.jdermsci.2011.04.001

Eyles, D., Almeras, L., Benech, P., Patatian, A., Mackay-Sim, A., McGrath, J., et al. (2007). Developmental vitamin D deficiency alters the expression of genes encoding mitochondrial, cytoskeletal and synaptic proteins in the adult rat brain. J. Steroid Biochem. Mol. Biol. 103, 538-545. doi: 10.1016/j.jsbmb.2006.12.096

Farooqui, J., Medrano, E., AbdelMalek, A., and Nordlund, J. (1993). The expression of proopiomelanocortin (POMC) and various POMC derived peptides in mouse and human skin. Ann. N.Y. Acad. Sci. 680, 508-510. doi: 10.1111/j.17496632.1993.tb19723.x

Ford, L., Graham, V., Wall, A., and Berg, J. (2006). Vitamin $\mathrm{D}$ concentrations in an UK inner-city multicultural outpatient population. Ann. Clin. Biochem. 43, 468-473. doi: 10.1258/000456306778904614

Gibson, G. E., Codd, M. B., and Murphy, G. M. (1997). Skin type distribution and skin disease in Ireland. Ir. J. Med. Sci. 166, 72-74. doi: 10.1007/BF02944190
Gower, B. A., Nagy, T. R., and Stetson, M. H. (1993). Role of prolactin and the gonads in seasonal physiological changes in the collared lemming (Dicrostonyx groenlandicus). J. Exp. Zool. 266, 92-101. doi: 10.1002/jez.1402660203

Guenther, A., and Trillmich, F. (2013). Photoperiod influences the behavioral and physiological phenotype during ontogeny. Behav. Ecol. 24, 402-411. doi: 10.1093/beheco/ars177

Gupta, S., and Murray, R. M. (1992). The relationship of environmental temperature to the incidence and outcome of schizophrenia. $\mathrm{Br}$. J. Psychiatry 160, 788-792. doi: 10.1192/bjp.160.6.788

Hadley, M. E. (1984). Endocrinology. Englewood Cliffs, NJ: Prentice Hall, Inc.

Hare, E., and Moran, P. (1981). A relation between seasonal temperature and the birth rate of schizophrenic patients. Acta. Psych. Scand. 63, 396-405. doi: 10.1111/j.16000447.1981.tb00687.x

Harrison, G., Glazebrook, C., Brewin, J., Cantwell, R., Dalkin, T., Fox, R., et al. (1997). Increased incidence of psychotic disorders in migrants from the Caribbean to the United Kingdom. Psychol. Med. 27, 799-806. doi: 10.1017/S0033291796004643

Harrison, H. E. (1966). A tribute to the first lady of public health (Martha M. Eliot). V. The disappearance of rickets. Am. J. Public Health Nations Health 56, 734-737. doi: 10.2105/AJPH.56.5.734

Harvey, I., Williams, M., McGuffin, P., and Toone, B. K. (1990). The functional psychoses in AfroCaribbeans. Br. J. Psychiatry 157, 515-522. doi: 10.1192/bjp.157.4.515

Health Research Board. (1972-1994). "Activities of Irish Psychiatric Hospitals and Units Dublin, Ireland," in Health board areas: all and first admissions, eds A. O'Connor, M. O'Hare, and D. Walsh (Dublin: Health Research Board).

Hickling, F. W., and Rodgers-Johnson, P. (1995). The incidence of first contact schizophrenia in Jamaica. Br. J. Psychiatry 167, 193-196. doi: 10.1192/bjp.167.2.193

Hiramoto, K., Yanagihara, N., Sato, E. F., and Inoue, M. (2003). Ultraviolet $B$ irradiation of the eye activates a nitric oxide-dependent hypothalamopituitary proopiomelanocortin pathway and modulates functions of alpha-melanocyte-stimulating hormone- responsive cells. $J$. Invest. Dermatol. 120, 123-127. doi: $\quad 10.1046 / j .1523-1747.2003$ 12004.x

Hoffman, K. (1978). Effects of short photoperiods on puberty, growth and moult in the Djungarian hamster (Phodopus sungorus). J. Reprod. Fertil. 54, 29-35. doi: 10.1530/jrf.0.0540029

Holzmann, H., Altmeyer, P., Stöhr, L., and Chilf, G. N. (1983). Modification of alpha-MSH by UVA irradiation of the skin. Hautarzt 34, 294-297.

Jablensky, A., Sartorius, N., Ernberg, G., Anker, M., Korten, A., Cooper, J. E., et al. (1992). Schizophrenia: manifestations, incidence and course in different cultures. A World Health Organization tencountry study. Psychol. Med. Monogr. Suppl. 20, 1-97. doi: $10.1017 /$ S0264180100000904

Jongbloet, P. H. (1975). "The effects of pre-ovulatory overripeness of human eggs on development" in Aging Gametes, ed R. J. Blandau (Basel: S. Karger), 300-329.

Karlsson, P., Stenberg, B., and Rosdahl, I. (2000). Prevalence of pigmented naevi in a Swedish population living close to the Arctic Circle. Acto Derm. Venereol. 80, 335-339. doi 10.1080/000155500459259

Kastin, A. J., Schally, A. V., Viosca, S., Barrett, L., and Redding, T. W. (1967a). MSH activity in the pituitaries of rats exposed to constant illumination. Neuroendocrinology 2, 257-262. doi: 10.1159/000121556

Kastin, A. J., Redding, T. W., and Schally, A. V. (1967b). MSH activity in rat pituitaries after pinealectomy. Proc. Soc. Exp. Biol. Med. 124 1275-1276. doi: 10.3181/00379727124-31986

Kelleher, M. J., Copeland, J. R., and Smith, A. J. (1974). High first admission rates for schizophrenia in the west of Ireland. Psychol. Med. 4, 460-462. doi 10.1017/S003329170004592X

Kendell, R. E., and Adams, W. (1991). Unexplained fluctuations in the risk for schizophrenia by month and year of birth. Br. J. Psych. 158, 758-763. doi: 10.1192/bjp.158.6.758

Khachaturian, H., Lewis, M. E., Tsou, K., and Watson, S. J. (1985). "Bendorphin, alpha-MSH, ACTH and related peptides" in Handbook of Neuroanatomy, Vol. 4, part I, eds A. Bjorklund and T. Hokfelt (Amsterdam: Elsevier Science), 216-272.

Kim, D. H., and Sung, S. (2010) The Plant Homeo Domain finger protein, VIN3-LIKE 2, is necessary for photoperiod-mediated epigenetic regulation of the floral repressor, MAF5. Proc. Natl. Acad. Sci. U.S.A. 107, 17029-17034. doi: 10.1073/pnas. 1010834107

Kinney, D. K., Teixeira, P., Hsu, D., Napoleon, S. C., Crowley, D. J., Miller, A., et al. (2009). Relation of schizophrenia prevalence to latitude, climate, fish consumption, infant mortality, and skin color: a role for prenatal vitamin d deficiency and infections? Schizophr. Bull. 35, 582-595. doi: 10.1093/schbul/sbp023

Kinney, D. K., Waternaux, C., Spivak, C., LeBlanc, D., and Vernooy, A. (1993). Schizophrenia risk predicted by meteorologic extremes near birth. Schizophr. Res. 9, 135. doi: 10.1016/0920-9964(93)90224-7

Konje, J. C., and Ladipo, O. A. (2000). Nutrition and obstructed labor. Am. J. Clin. Nutr. 72, 291S-297S.

Krause, P. F., and Flood, K. L. (1997). Weather and Climate Extremes, TEC-0099. Alexandria, VA: U.S. Army Corps of Engineers.

Kuljzenko, A. (1933). Statistika O Dusevnim Bolesnicama Jugoslavije Za God, 1930 Te Znacenje Dobicenih Resultata. Glasnik Centralnog Higijenskog Zavoda $\mathrm{Br}$ 10. g. 8.

Kumar, V., Rani, S., Malik, S., Trivedi, A. K., Schwabl, I., Helm, B., et al. (2007). Daytime light intensity affects seasonal timing via changes in the nocturnal melatonin levels. Naturwissenschaften 94, 693-696. doi: 10.1007/s00114-007-0243-1

LaHoste, G. J., Olson, G. A., Kastin, A. J., and Olson, R. D. (1980). Behavioral effects of melanocyte stimulating hormone. Neurosci. Behav. Rev. 4, 9-16. doi: 10.1016/0149-7634(80)90022-6

Lee, T., and Zucker, I. (1988). Vole infant development is influenced perinatally by maternal photoperiodic history. Am. J. Physiol. 255, R831-R838.

Lewis, M. S., and Griffin, P. A. (1981). An explanation for the season of birth effect in schizophrenia and certain other diseases. Psychol. Bull. 89, 589-596. doi: 10.1037/00332909.89.3.589

Lin, J. Y., and Fisher, D. E. (2007). Melanocyte biology and skin pigmentation. Nature 445, 843-850. doi: 10.1038/nature05660

Liu, J., Liu, J., Linderholm, H. W., Chen, D., Yu, Q., Wu, D., et al. (2012). Observation and calculation of the solar radiation on the Tibetan Plateau. Energ. Covers. Manage. 57, 23-32. doi: 10.1016/j.enconman.2011.12.007

Logue, J. J. (1984). Regional variations in the annual cycle of 
rainfall in Ireland as revealed by principal component analysis. J. Climatol. 4, 597-607. doi: 10.1002/joc.3370040604

Luccini, E., Cede, A., Piacentini, R. D. (2003). Effect of clouds on UV and total irradiance at Paradise Bay, Antarctic Peninsula, from a summer 2000 campaign. Theor. Appl. Climatol. 75, 105-116.

Machado, I., González, P., Schiöth, H. B., Lasaga, M., and Scimonelli, T. N. (2010). $\alpha$-Melanocyte-stimulating hormone $(\alpha-\mathrm{MSH})$ reverses impairment of memory reconsolidation induced by interleukin-1 beta (IL-1 beta) hippocampal infusions. Peptides 31, 2141-2144. doi: 10.1016/j.peptides.2010.07.018

Maharajh, H. D., and Konings, M. (2005). Cannabis and suicidal behaviour among adolescents: a pilot study from Trinidad. ScientificWorldJournal 5, 576-585. doi: 10.1100/tsw.2005.79

Mahy, G. E., Mallett, R., Leff, J., and Bhugra, D. (1999). First-contact incidence rate of schizophrenia on Barbados. Br. J. Psychiatry 175, 28-33. doi: 10.1192/bjp.175.1.28

Marinkovic, S. P., Orlandic, L. B., Skoric, S. B., and Karadzic, B. C. (2012). Nest-site preference of Griffon vulture (Gyps Fulvus) in Herzegovina. Arch. Biol. Sci. 64, 385-392. doi: 10.2298/ABS1201385M

McGovern, D., and Cope, R. V. (1987). First psychiatric admission rates of first and second generation Afro Caribbeans. Soc. Psychiatry 22, 139-149. doi: 10.1007/BF00583848

McGrath, J. J., and Welham, J. L., (1999). Season of birth and schizophrenia: a systematic review and meta-analysis of data from the Southern Hemisphere. Schizophr. Res. 35, 237-242. doi: 10.1016/S0920-9964(98)00139-X

McGrath, J. J., Eyles, D. W., Pedersen, C. B., Anderson, C., Ko, P., Burne, T H., et al. (2010a). Neonatal vitamin D status and risk of schizophrenia: a population-based case-control study. Arch. Gen. Psychiatry 67, 889-894. doi: 10.1001/archgenpsychiatry.2010.110

McGrath, J., Welham, J., Scott, J., Varghese, D., Degenhardt, L., Hayatbakhsh, M. R., et al. (2010b). Association between cannabis use and psychosis-related outcomes using sibling pair analysis in a cohort of young adults. Arch. Gen. Psychiatry 67, 440-447. doi: 10.1001/archgenpsychiatry.2010.6

McGrath, J., Selten, J. P., and Chant, D. (2002). Long-term trends in sunshine duration and its association with schizophrenia birth rates and age at first registration-data from Australia and the Netherlands. Schizophr. Res. 54, 199-212. doi: 10.1016/S0920-9964(01)00259-6

McGuire, P. K., Jones, P., Harvey, I., Williams, M., McGuffin, P., and Murray, R. M. (1995). Morbid risk of schizophrenia for relatives of patients with cannabis-associated psychosis. Schizophr. Res. 15, 277-281. doi: 10.1016/0920-9964(94)00053-B

McManus, S. (1931). The Story of the Irish Race. New York, NY: DevinAdair Company.

Messias, E. L., Cordeiro, N. F., Sampaio, J. J., Bartko, J. J., and Kirkpatrick, B. (2001). Schizophrenia and season of birth in a tropical region: relationship to rainfall. Schizophr. Res. 48, 227-234. doi: 10.1016/S0920-9964 (00)00058-X

Messias, E., Mourao, C., Maia, J., Campos, J. P., Ribeiro, K., Ribeiro, L., et al. (2006). Season of birth and schizophrenia in Northeast Brazil: relationship to rainfall. J. Nerv. Ment. Dis. 194, 870-873. doi: 10.1097/ 01.nmd.0000243762.63694.e6

Miller, C. L. (2009). The evolution of schizophrenia: a model for selection by infection, with a focus on NAD. Curr. Pharm. Des. 15, 100-109. doi: 10.2174/138161209787185805

Miller, C. L. (2013). On the mechanism of action of antipsychotic drugs: a chemical reaction not receptor blockade. Curr. Drug Discov. Technol. 10, 195-208. doi: 10.2174/1570163811310030003

Miller, C. L., Hruby, V. J., Matsunaga, T. O., and Bickford, P. C. (1993). Alpha-MSH and $\mathrm{MCH}$ are functional antagonists in a CNS auditory gating paradigm. Peptides 14, 431-440. doi: 10.1016/0196-9781(93)90128-4

Miller, C. L., Murakami, P., Ruczinski, I., Ross, R. G., Sinkus, M., Sullivan, B., et al. (2009). Two complex genotypes relevant to the kynurenine pathway and melanotropin function show association with schizophrenia and bipolar disorder. Schizophr. Res. 113, 259-267. doi: 10.1016/j.schres.2009.05.014

Miller, C. L. (2011). The kynurenine pathway: modeling the interaction between genes and nutrition in schizophrenia. J. Orthomol. Med. 26, 59-84.

Mills, L. S., Zimova, M., Oyler, J., Running, S., Abatzoglou, J. T., and Lukacs, P. M. (2013). Camouflage mismatch in seasonal coat color due to decreased snow duration. Proc. Natl. Acad.
Sci. U.S.A. 110, 7360-7365. doi: 10.1073/pnas. 1222724110

Moore, T. H., Zammit, S., LingfordHughes, A., Barnes, T. R., Jones, P. B., Burke, M., et al. (2007). Cannabis use and risk of psychotic or affective mental health outcomes: a systematic review. Lancet 370, 319-328. doi: 10.1016/S01406736(07)61162-3

Morgan, C., Thomas, R. E., Ma,W., Novotny, M. V., and Cone, R. D. (2004). Melanocortin-5 receptor deficiency reduces a pheromonal signal for aggression in male mice. Chem. Senses 29, 111-115. doi: 10.1093/chemse/bjh011

Mortensen, P. B., Pedersen, C. B., Westergaard, T., Wohlfahrt, J., Ewald, H., Mors, O., et al. (1999). Effects of family history and place and season of birth on the risk of schizophrenia. $N$. Engl. J. Med. 340, 603-608. doi: 10.1056/NEJM199902253400803

Muschick, M., Barluenga, M., Salzburger, W., and Meyer, A. (2011). Adaptive phenotypic plasticity in the Midas cichlid fish pharyngeal jaw and its relevance in adaptive radiation. BMC Evol. Biol. 11:116. doi: 10.1186/1471-2148-11-116

Nagy, T. R., Gower, C. A., and Stetson, M. H. (1993). Development of collared lemmings, Discrostonyx groenlandicus, is influenced by preand postweaning photoperiods. J. Exp. Zool. 267, 533-542. doi: 10.1002/jez.1402670508

Nahon, J. L. (1994). The melaninconcentrating hormone: from the peptide to the gene. Crit. Rev. Neurobiol. 8, 221-262.

Nahon, J. L. (2006). The melanocortins and melanin-concentrating hormone in the central regulation of feeding behavior and energy homeostasis. $C R$ Biol. 329, 623-638. discussion: 653-655. doi: 10.1016/j.crvi.2006.03.021

O'Callaghan, E., Gibson, T., Colohan, H. A., Walshe, D., Buckley, P., Larkin, C., et al. (1991). Season of birth in schizophrenia, evidence for confinement of an excess of winter births to patients without a family history of mental disorder. Br. J. Psychiatry 158, 764-768. doi: 10.1192/bjp. 158.6.764

O'Donohue, T. L., and Dorsa, D. M. (1982). The opiomelanotropinergic neuronaland endocrine systems. Peptides 3, 353-395. doi: 10.1016/0196-9781(82)90098-5

O'Hare, A., Walsh, D., and Torrey, F. (1980). Seasonality of schizophrenic births in Ireland.
Br. J. Psychiatry 137, 74-77. doi: 10.1192/bjp.137.1.74

Pallast, E. G. M., Jongbloet, P. H., Straatman, H. M., and Zielhuis, G. A. (1994). Excess seasonality of births among patients with schizophrenia and seasonal ovopathy. Schizophr. Bull. 20, 269-276. doi: 10.1093/schbul/20. 2.269

Pan, P., Jin, D. H., ChatterjeeChakraborty, M., Halievski, K., Lawson, D., Remedios, D., et al (2013). The effects of vitamin D(3) during pregnancy and lactation on offspring physiology and behavior in sprague-dawley rats. Dev. Psychobiol. doi: 10.1002/dev.21086. [Epub ahead of print].

Papp, B., and Erzberger, P. (2007). Contributions to the Bryophyte flora of Montenegro. Studia Bot. Hung. 38, 79-94.

Prendergast, B. J., and Zucker, I. (2012). Photoperiodic influences on ultradian rhythms of male Siberian hamsters. PLoS ONE 7:e41723. doi: 10.1371/journal.pone.0041723

Prendergast, B. J., Kelly, K. K., Zucker, I., and Gorman, M. R. (1996). Enhanced reproductive responses to melatonin in juvenile Siberian hamsters. Am. J. Physiol. 217, R1041-R1046.

Pulver, A. E., Moorman, C. C., Brown, C. H., McGrath, J. A., and Wolyniec, P. S. (1990). Age-incidence artifacts do not account for the seasonof-birth effect in schizophrenia. Schizophr. Bull. 16, 13-15. doi: 10.1093/schbul/16.1.13

Reppert, S. M. (1985). Maternal entrainment of the developing circadian system. Ann. N.Y. Acad. Sci. 453, 162-169. doi: 10.1111/j.17496632.1985.tb11808.x

Rodvall, Y., Wahlgren, C. F., Ullén, H., and Wiklund, K. (2007). Common melanocytic nevi in 7-year-old schoolchildren residing at different latitudes in Sweden. Cancer Epidemiol. Biomarkers Prev. 16, 122-127. doi: 10.1158/1055-9965. EPI-06-0426

Saha, S., Chant, D. C., Welham, J. L., and McGrath, J. J.,(2006). The incidence and prevalence of schizophrenia varies with latitude. Acta. Psychiatr. Scand. 114, 36-39. doi: $\quad 10.1111 / \mathrm{j} .1600-0447.2005$. 00742.x

Sartorius, N., Jablensky, A., Korten, A., Ernberg, G., Anker, M., Cooper, J. E., et al. (1986). Early manifestations and first-contact incidence of schizophrenia in different cultures. A preliminary report on the initial evaluation phase of the WHO Collaborative 
Study on determinants of outcome of severe mental disorders. Psychol. Med. 16, 909-928. doi: $10.1017 /$ S0033291700011910

Schwarcz, R., Bruno, J. P., Muchowski, P. J., Wu, H. Q. (2012). Kynurenines in the mammalian brain: when physiology meets pathology. Nat. Rev. Neurosci. 13, 465-477. doi: 10.1038/nrn3257

Severinsen, J. E., Als, T. D., Binderup, H., Kruse, T. A., Wang, A. G., Vang, M., et al. (2006). Association analyses suggest GPR24 as a shared susceptibility gene for bipolar affective disorder and schizophrenia. Am. J. Med. Genet. B Neuropsychiatr. Genet. 141B, 524-533. doi: 10.1002/ajmg.b. 30335

Sharpley, M., Hutchinson, G., McKenzie, K., and Murray, R. M. (2001). Understanding the excess of psychosis among the African-Caribbean population in England. Review of current hypotheses. Br. J. Psychiatry Suppl. 40, s60-s68. doi: 10.1192/bjp.178. $40 . s 60$

Shaw, D., and Goldman, B. D. (1995). Gender differences in influence of prenatal photoperiods on postnatal pineal melatonin rhythms and serum prolactin and folliclestimulating hormone in the Siberian hamster (Phodopus sungorus). Endocrinology 136, 4237-4246. doi: 10.1210/en.136.10.4237

Shen, Y., Fu, W. Y., Cheng, E. Y., Fu, A. K., and Ip, N. Y. (2013). Melanocortin-4 receptor regulates hippocampal synaptic plasticity through a protein kinase A-dependent mechanism. J. Neurosci. 33, 464-472. doi: 10.1523/JNEUROSCI.3282-12.2013

Sicking, L., and Abreu-Ferreira, D. (2008). Beyond the Catch: Fisheries of the North Atlantic, the North Sea and the Baltic, 900-1850. Leiden: Brill Academic Pub.

Small, T. W., and Moore, I. T. (2009). Seasonal neuroplasticity of the song control system in tropical, flexibly, and opportunistically breeding birds. Gen. Comp. Endocrinol. 163, 135-141. doi: 10.1016/j.ygcen.2009. 01.002

Stetson, M. H., Elliott, J. A., and Goldman, B. D. (1986). Maternal transfer of photoperiodic response of prepubertal Djungarian hamsters (Phodopus sungorus sungorus). Bio. Reprod. 34, 664-669. doi: 10.1095/biolreprod34.4.664

Sugarman, P. A., and Craufurd, D. (1994). Schizophrenia in the Afro-Caribbean community. $\mathrm{Br}$. J. Psychiatry 164, 474-480. doi: 10.1192/bjp.164.4.474

Taherzadeh, S., Sharma, S., Chhajlani, V., Gantz, I., Rajora, N., Demitri, M. T., et al. (1999). $\alpha$-MSH and its receptors in regulation of tumor necrosis factor-alpha production by human monocyte/macrophages. Am. J. Physiol. 276, R1289-R1294

Taylor, A., and Namba, K. (2001). In vitro induction of CD25+ $\mathrm{CD} 4+$ regulatory $\mathrm{T}$ cells by the neuropeptide alpha-melanocyte stimulating hormone (alpha-MSH). Immunol. Cell. Biol. 79, 358-367. doi: $\quad 10.1046 /$ j.1440-1711.2001. 01022.x

Taylor, M. W., and Feng, G. S. (1991). Relationship between interferon-gamma, indoleamine 2,3-dioxygenase, and tryptophan catabolism. FASEB J. 5, 2516-2522.

Tebbich, S., Sterelny, K., and Teschke, I. (2010). The tale of the finch: adaptive radiation and behavioural flexibility. Phil. Trans. R. Soc. B Biol Sci. 365,
1099-1109. doi: 10.1098/rstb.2009. 0291

Torrey, E. F., Miller, J., Rawlings, R., and Yolken, R. H. (1997) Seasonality of births in schizophrenia and bipolar disorder: a review of the literature. Schizophr. Res. 28 1-38. doi: 10.1016/S0920-9964(97) 00092-3

Valverde, P., Healy, E., Jackson, I., Rees, J. L., and Thody, A. J. (1995). Variants of the melanocytestimulating hormone receptor gene are associated with red hair and fair skin in humans. Nat. Genet. 11, 328-330. doi: 10.1038/ ng1195-328

Van Buskirk, J., McCollum, S. A., and Werner, E. (1997). Natural selection for environmentally induced phenotypes in tadpoles. Evolution 51, 1983-1992. doi: 10.2307/ 2411018

Walsh, D. (1968). Hospitalized psychiatric morbidity in the Republic of Ireland. Br. J. Psychiatry 114, 11-14. doi: 10.1192/bjp.114.506.11

Watson, C. G. (1990). Schizophrenic birth seasonality and the ageincidence artifact. Schizophr. Bull. 16, 5-10. discussion: 17-28.

Walton, J. C., Weil, Z. M., and Nelson, R. J. (2011). Influence of photoperiod on hormones, behavior, and immune function. Front Neuroendocrinol. 32, 303-319. doi: 10.1016/j.yfrne.2010.12.003

Weaver, D. R., Keohan, J. T., and Reppert, S. M. (1987). Definition of a prenatal sensitive period for maternal-fetal communication of day length. Am. J. Physiol. 253, E701-E704.

Wessely, S., Castle, D., Der, G., and Murray, R. (1991). Schizophrenia and Afro-Caribbeans. A casecontrol study. Br. J. Psychiatry 159, 795-801. doi: 10.1192/bjp.159.6.795
Woodham-Smith, C. (1962). The Great Hunger, Ireland 1845-1849. New York, NY: Harper and Row.

Wund, M. A., Baker, J. A., Clancy, B., Golub, J. L., and Foster, S A. (2008). A test of the "flexible stem" model of evolution: ancestral plasticity, genetic accommodation, and morphological divergence in the threespine stickleback radiation. Am. Nat. 172, 449-462. doi: 10.1086/590966

Zeitzer, J. M., Dijk, D. J., Kronauer, R., Brown, E., and Czeisler, C. (2000). Sensitivity of the human circadian pacemaker to nocturnal light: melatonin phase resetting and suppression. J. Physiol. 526, 695-702. doi: 10.1111/j.14697793.2000.00695.x

Conflict of Interest Statement: The author declares that the research was conducted in the absence of any commercial or financial relationships that could be construed as a potential conflict of interest.

Received: 21 April 2013; paper pending published: 13 May 2013; accepted 20 June 2013; published online: 09 July 2013.

Citation: Miller CL (2013) Evidence for phenotypic plasticity in response to photic cues and the connection with genes of risk in schizophrenia. Front. Behav. Neurosci. 7:82. doi: 10.3389/ fnbeh.2013.00082

Copyright (c) 2013 Miller. This is an open-access article distributed under the terms of the Creative Commons Attribution License, which permits use, distribution and reproduction in other forums, provided the original authors and source are credited and subject to any copyright notices concerning any thirdparty graphics etc. 